\title{
UNCLASSIFIED
}

\section{$\perp$ \\ THE EFFECT OF HEAT TREATMENT ON INTERNAL FRICTION IN ROLLED URANIUM BARS}

\author{
S. D. Hart
}

\section{LEGAL NOTICE}

This report wos prepared as an account of Government sponsored work. Neither the United States, nor the Commission, nor any person acting on behalf of the Commission:

A. Makes any warranty or representation, express or implied, with respect to the accuracy, completeness, or usefulness of the information contained in this report, or that the use of, any information, apporatus, method, or process disclosed in this report may not infringe privately owned rights; or

B. Assumes any liabilities with respect to the use of, or for damages resulting from the use of any informotion, apparatus, mathod, or process disclosed in this report.

As used in the above, "person acting on behalf of the Commission" includes any employee or contractor of the Commission to the extent that such employee or contractor prepares, handles or distributes, or provides occess to, any information pursuant to his employment or contract with the Commission.

\section{CLASSIFICATION CANCELLED}

DATE FEB $₹ 71957$

per

For The Atomic Energy Commission

- 72

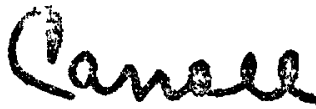

Chief, Deciassification Branch

Work Performed under Contract No. AT(30-1)-1344 Atomic Energy Commission - New York Operations Office

This document is PUBLICLY RELEASABLE ORO ReVIew Team Authorizing Official

Date $11-9-2010$

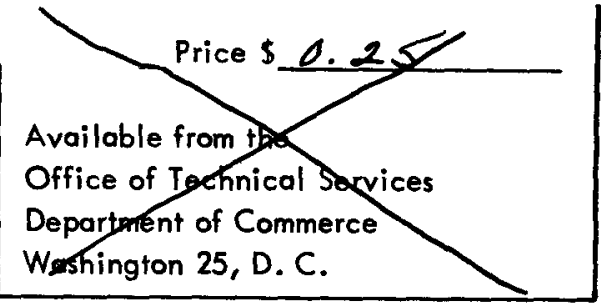

NAVAL RESEARCH LABORATORY

Washington. D.C.

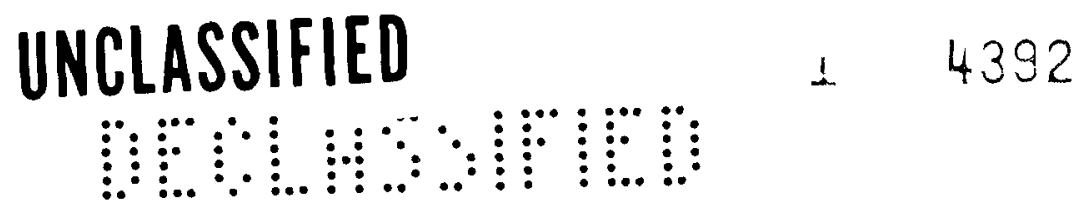


2 औ" 


\section{DISCLAIMER}

This report was prepared as an account of work sponsored by an agency of the United States Government. Neither the United States Government nor any agency Thereof, nor any of their employees, makes any warranty, express or implied, or assumes any legal liability or responsibility for the accuracy, completeness, or usefulness of any information, apparatus, product, or process disclosed, or represents that its use would not infringe privately owned rights. Reference herein to any specific commercial product, process, or service by trade name, trademark, manufacturer, or otherwise does not necessarily constitute or imply its endorsement, recommendation, or favoring by the United States Government or any agency thereof. The views and opinions of authors expressed herein do not necessarily state or reflect those of the United States Government or any agency thereof. 


\section{DISCLAIMER}

Portions of this document may be illegible in electronic image products. Images are produced from the best available original document. 
Introduction

This study of internal friction was undertaken with the particular objective of determining whether this parameter could be correlated with the presence of locked-in stresses which might cause dimensional instability in the bars during reactor operation.

Experimental Procedure

The internal friction data are considered in terms of:

1. The condition of the bars as received w1th regard to their metallurgical histories.

2. The additional treatment given them in this laboratory, principally mechanical shock.

It is assumed that the measurements in the first category were made a sufficiently long time after fabrication so that the aging phenomena which might affect internal friction had reached a stable condition. For the observations made under the second classification the specimens were given a mechanical shock by dropping them about 30 inches so as to land endways upon a large steel anvil。 Decrements were measured immediately before and after this shock as well as at later time invervals until recovery was nearly complete.

Table 1 lists the physical dimensions of the specimens used in this experiment, together with the heat treatments. The apparatus and technique for measuring decrement have been described in an earlier reportl. Using the first flexural mode of vibration, the resonant frequencies at which the measurements were made fell between 1500 and 1600 cps.

Results

Considering first the tests under classification 1 , namely, the bars as received, there seems to be some correlation between log-decrement and fabrication temperature. As shown in Figure 1, the highest fabrication temperatures are associated with the lowest decrements. This may be attributed to a finer grain size for the low fabrication temperatures with attendant larger population of dislocations. The finer grain size alone may, at these temperatures, give.

1 Progress Report for March 1952 thru August 1952, NYO-3787 


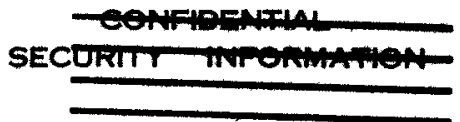

rise to a higher internal friction through grain boundary flow, but the fact that the log-decrement increases with amplitude of vibrations as shown in Figure 2, leads to the conclusion that it is predominantly due to motion of dislocations 2,3 . Some support is given to this conclusion by the fact that the internal friction does not vary with frequency.

The lack of information on the history of the bars in Groups A and B makes an inter-comparison of the several groups of doubtful value. However, in general, the decrements of the Group A bars were greater than those of Groups B and C, but those of Group B fall in the midst of Group C. There was no correlation between decrement and beta treatment.

The results under classification (2) are considered next, namely, the effects of mechanical shock. The aging time after mechanical shock shown in Figures 3 and 4 was about the same for all bars the first time they were dropped.

Figure 5 shows that, if the mechanlcal shock is repeated a number of times until no further change in decrement occurs, no significant change in aging time takes place. Again there is some correlation between fabrication temperature and behavior after aging in the Group $C$ bars (Figure 4) The initial increase in decrement and the slope of the aging curve are greater, the lower the fabrication temperature. This appears to be an example of cold-work induced internal friction. As such it would be caused by small dislocations easily removed by a mild heat treatment. To test this, two bars with similar history except that one had been subjected to mechanical shock, were heat treated for one hour at $300^{\circ} \mathrm{C}$, with the results shown in Figure 6. Here it is seen that after removal from the oven both bars behaved in an almost identical manner.

The decrement was found to be very sensitive to handilng. Decrement detefminations were erratic when made soon after putting the bands 4 of magnetic material on each end of the bars . By having bands and slings made up for each bar it was possible to leave the bars undisturbed during the aging test, thereby reducing the point scatter.

ZT.A.Read, Phys。Rev. 58, 371 (1940)

3 A. S. Novick, Progress In Metal Physics, Vol。 4 (1953)

These bands represent a slight modification of the procedure described in ref. 1. The bands described earlier were about .05" thick and were cemented on. For the current tests split bands .05" thick were sprung onto the bar. At first there was only one pair which was placed on each bar in turn.

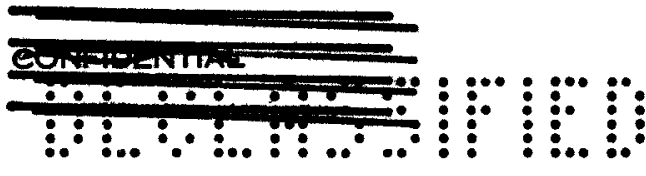




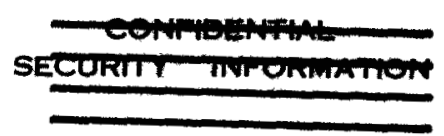

\section{Conclusions}

Although the curve drawn through the average values for the decrement in each temperature class, Figure 1, suggests a slight correlation between internal friction and the fabrication temperature for Group C specimens, the scatter within a class is sufficient to preclude the correct classification of an unknown (as to fabrication temperature) bar on the basis of internal friction. For the Group $B$ bars only the annealing conditions are known. Again it is found to be impossible to differentiate between the members of the group on the basis of internal friction. In fact, the scatter here is worse than in the case of Group $C$. Table, 2 shows that there is no correlation between decrement and heat treatment in Group B. It is concluded therefore, that internal friction is too sensitive to handling and conditions of test to be used as an industrial control in this instance. 
Table 1

Description of Specimens

Bar No.

Diameter

(Inches)
Length

(inches) Remarks

Group A

\begin{tabular}{|c|c|c|c|}
\hline $2779-3-16$ & $0.9971 \pm .0005$ & 8.05 & There are no \\
\hline $2889-4-6$ & $0.9874 \pm .0002$ & 8.06 & avallable on the \\
\hline $3018-2-20$ & $0.9964 \pm .0001$ & 8.05 & $\begin{array}{l}\text { specimens } \\
\text { A. }\end{array}$ \\
\hline $3077-F-18$ & $0.9871 \pm .0002$ & 8.06 & \\
\hline $3077-F-21$ & $0.9877 \pm .0001$ & 8.06 & \\
\hline
\end{tabular}

Group B
$2896-1-1(\alpha)$
$0.936 \pm .002$
8.07
Heat treated at $600^{\circ} \mathrm{C} 1 / 2$ hour
$2892-4-1(\alpha)$
$0.993 \pm .001$
8.09
Heat treated at $600^{\circ} \mathrm{C} 1 / 2$ hour
$A B C-1-13(B)$
$0.9904 \pm .0003$
8.06
Heat treated at $720^{\circ} \mathrm{C} 70$ seconds.
$2896-2-27(\beta)$
$0.9940 \pm .0003$
8.06
Heat treated at $720^{\circ} \mathrm{C} 70$ seconds.
$6339-B-22(\beta) \quad 0.988 \pm .001$
8.05
Heat treated at $720^{\circ} \mathrm{C} 70$ seconds

Group C (12 bars, 4 in each temperature class)
$4 D 62 \mathrm{I}^{-} \mathrm{A}$
$630^{\circ} \mathrm{C}$
$0.9270 \pm .0002$
8.00
Rough rolled to 1-1/2" dia.at $600^{\circ} \mathrm{C}$. Finish rolled at $630^{\circ} \mathrm{C}$ to $1^{\prime \prime}$ dia. then ground.
4D621-C $550^{\circ} \mathrm{C}$
4D621-C $480^{\circ} \mathrm{C}$
$0.9270 \pm .0002$
8.00
Finish rolled at $550^{\circ} \mathrm{C}$ to I" dia. then ground.
$0.9270 \pm .0002$
8.00
Finish rolled at $480^{\circ} \mathrm{C}$ to I" d1a. then ground. 


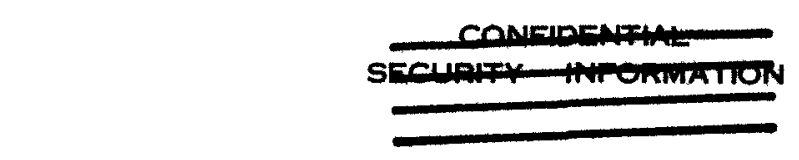

\section{Table 2}

Logarithmic Decrement Before Mechanical Shock

Bar

Number
Fabrication Temperature (degrees C)
Annealing

Temperature

(degrees C)
Log. Decrement

as Recelved

Group A

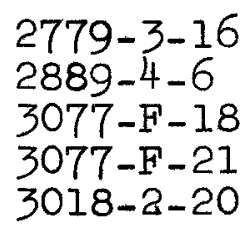

$*$
$*$
$*$
$*$
$*$

$*$
$*$
$*$
$*$
$*$

$2.9 \times 10^{-3}$

3.1

3.1

3.2

3.1

Group B

$\begin{array}{llll}2892-4-1(\alpha) & * & 600 & 1.41 \\ 2896-1-1(\alpha) & * & 600 & 1.77 \\ 2896-2-27(\beta) & * & 720 & 1.41 \\ 6339-B-22(\beta) & * & 720 & 1.31 \\ A B C-1-13(\beta) & * & 720 & 1.58\end{array}$

Group $\underline{\mathrm{C}}$

480-1

$-2$

$-3$

480

$"$

480

2.00

1.93

1.99

$550-1$

$-2$

$-3$

"

"1

2.05

$630-1$

$-2$

$-3$

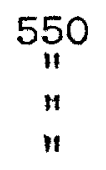

550

1.38

1.79

1.38

1.33

$n$

630

1.21

1.36

"

1.18

n

1.21

* These temperatures were not ava1lable.

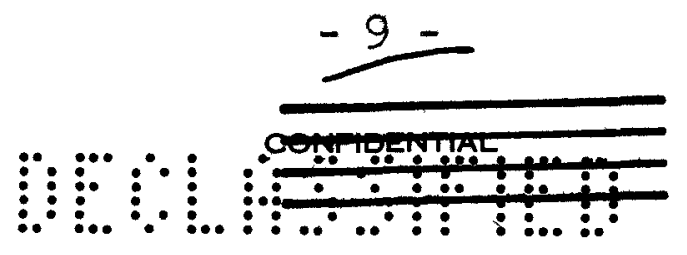




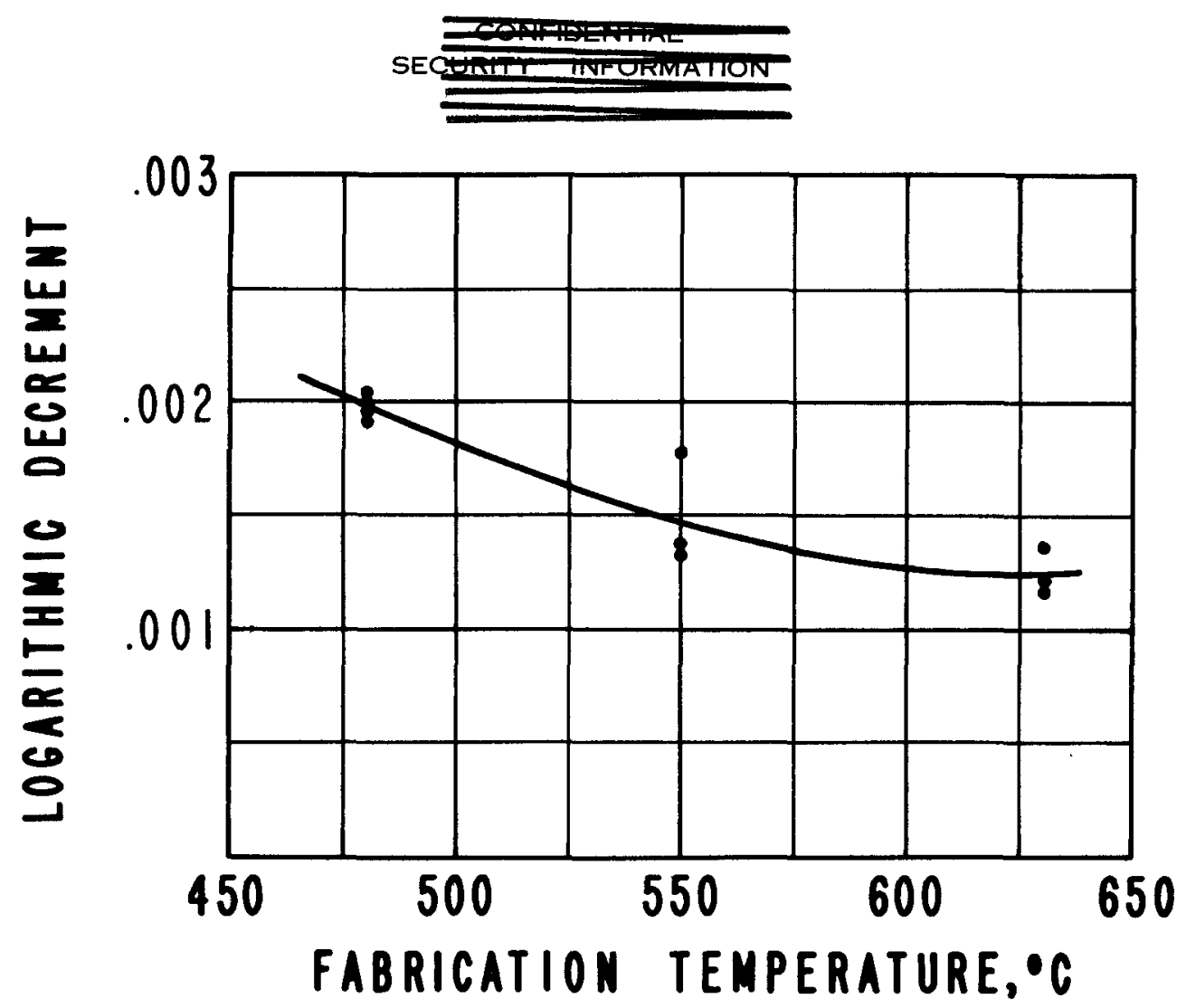

FIGURE I VARI ATION OF DECREMENT WITH FABRICATION TEMPERATURE.

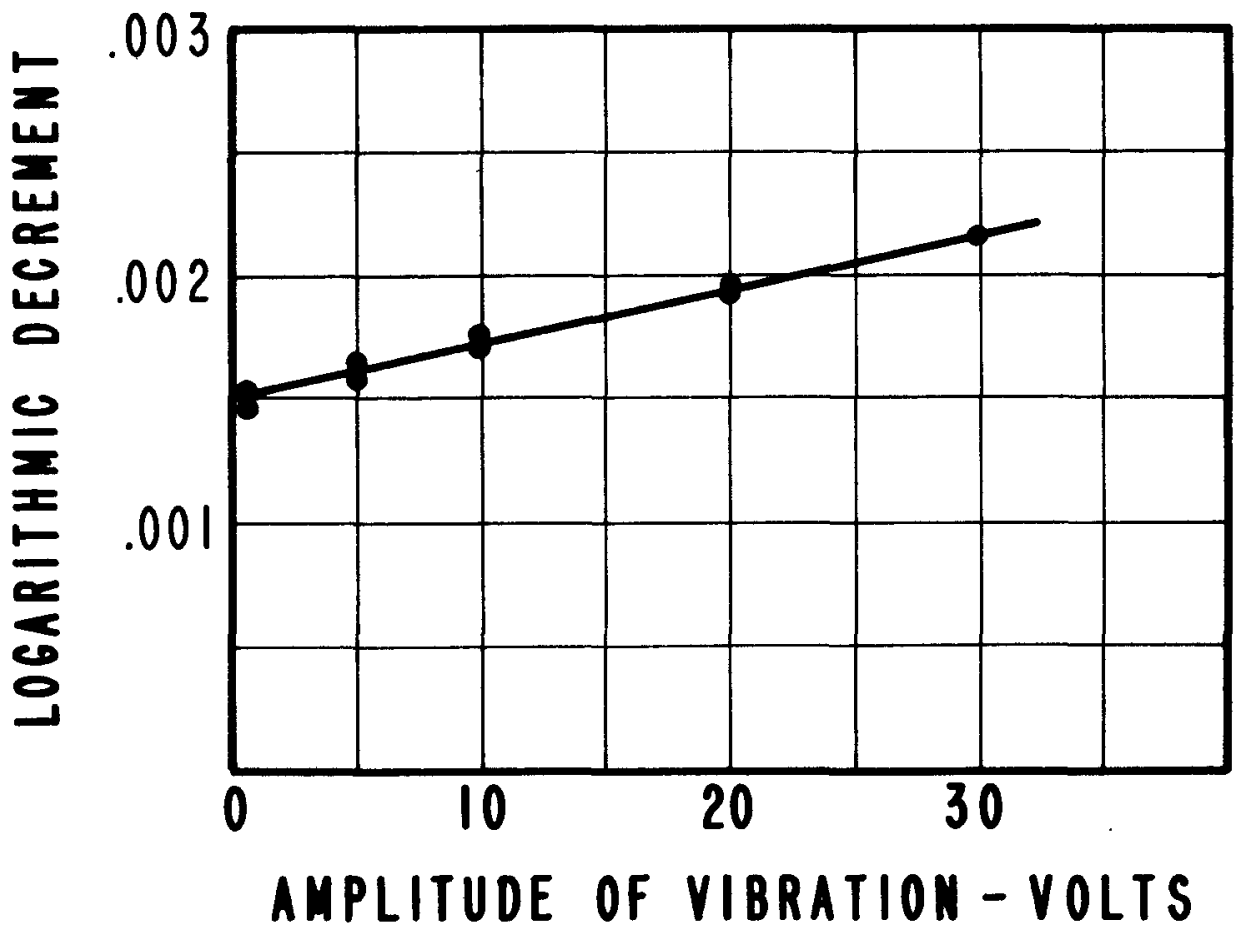

FIGURE 2 VARIATION OF DECREMENT WITH AMPLITUdE OF VIBRATION.

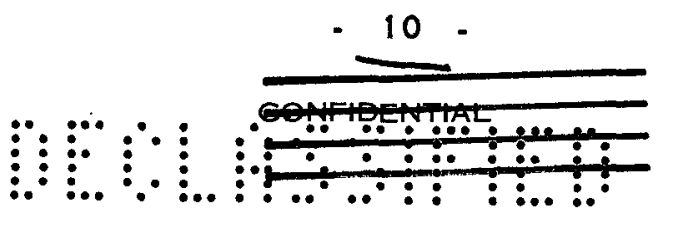




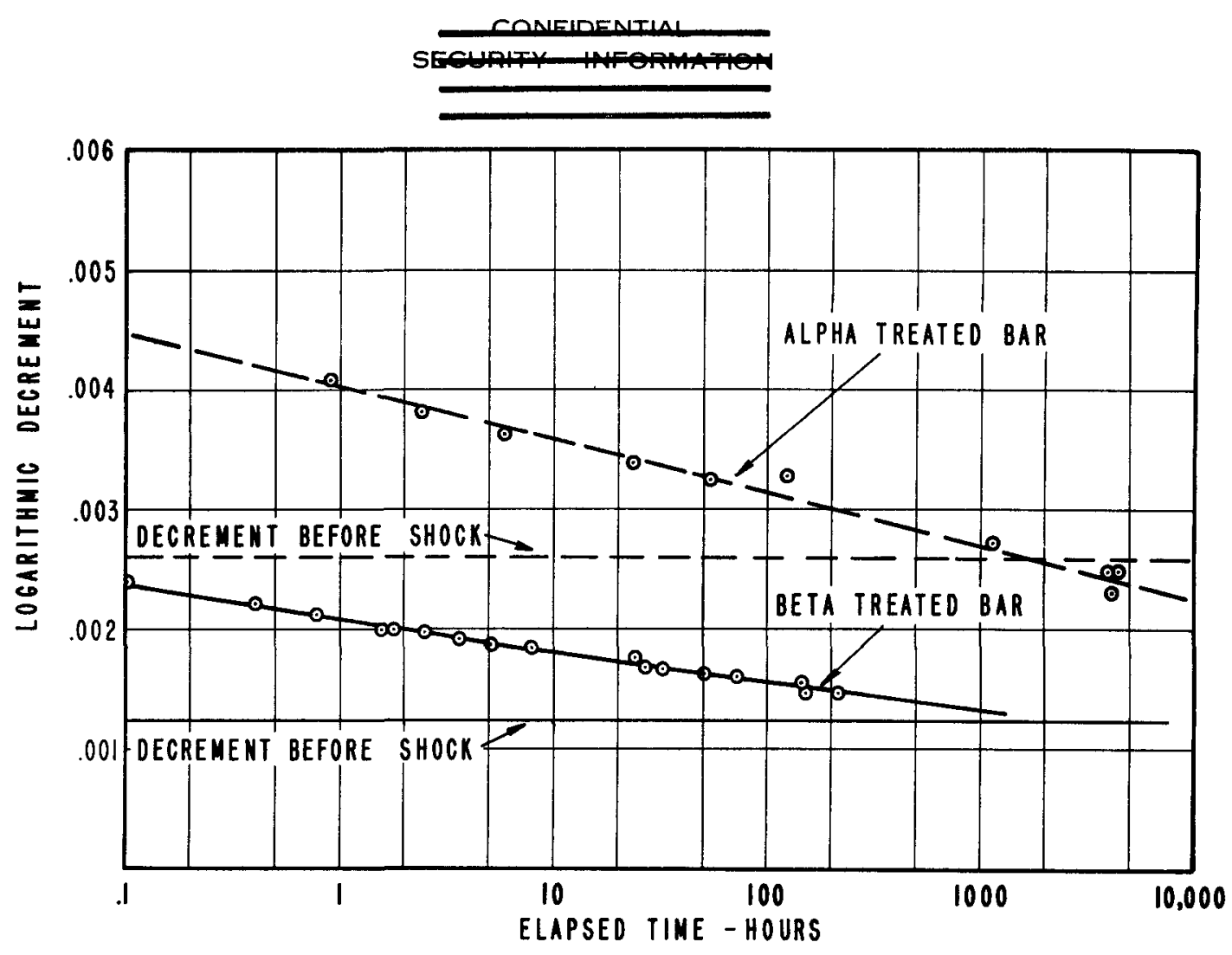

FI GURE 3 RECOVERY OF DECREMENT AFter MECHANICAL SHOCK.

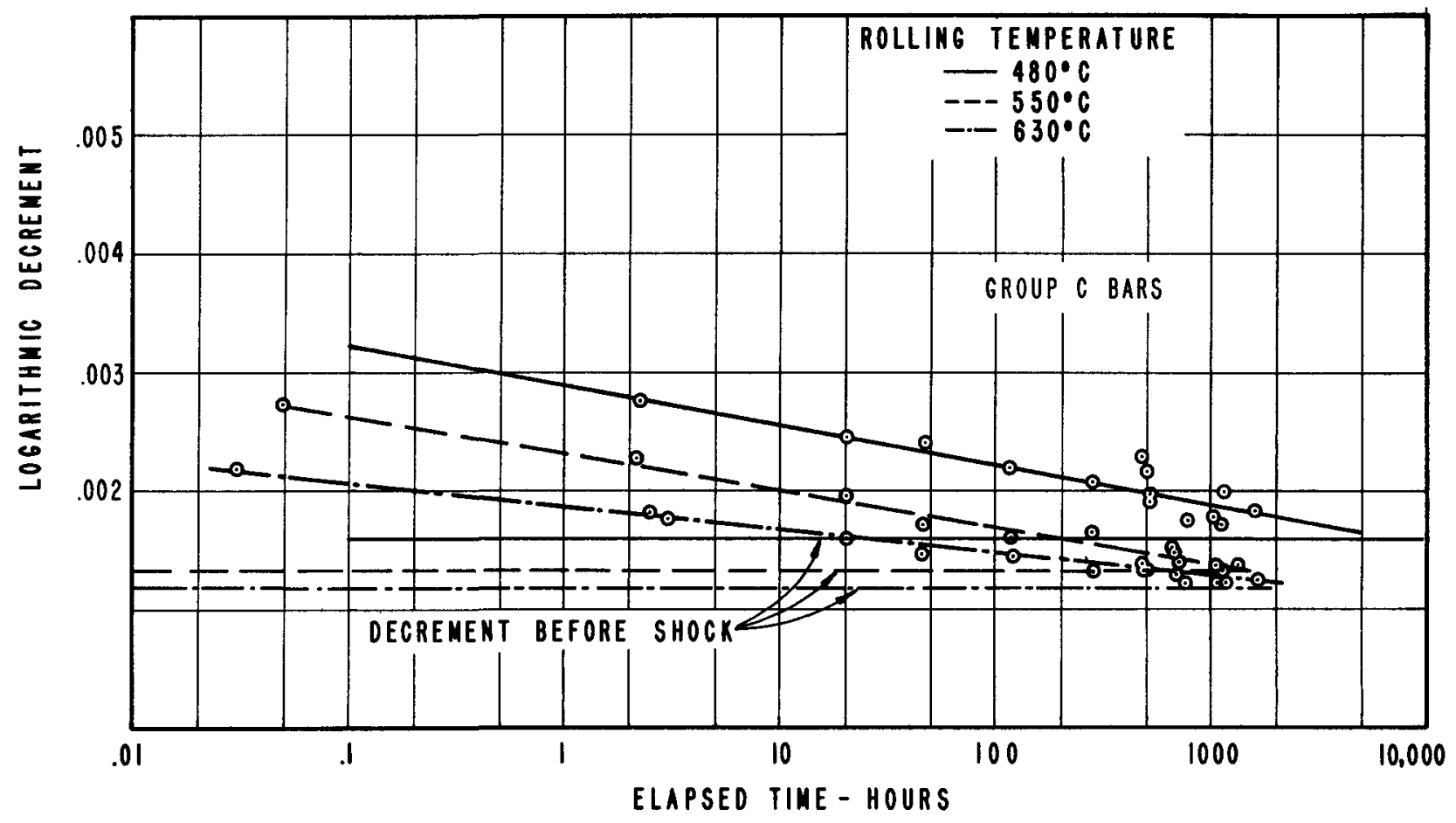

FIGURE 4

Recovery Of Decrement after Mechanical SHOCK.

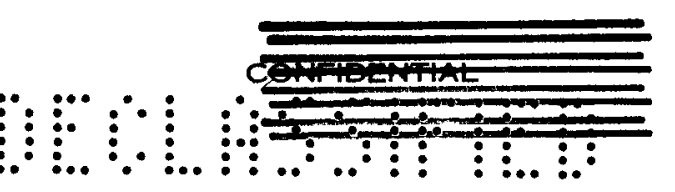




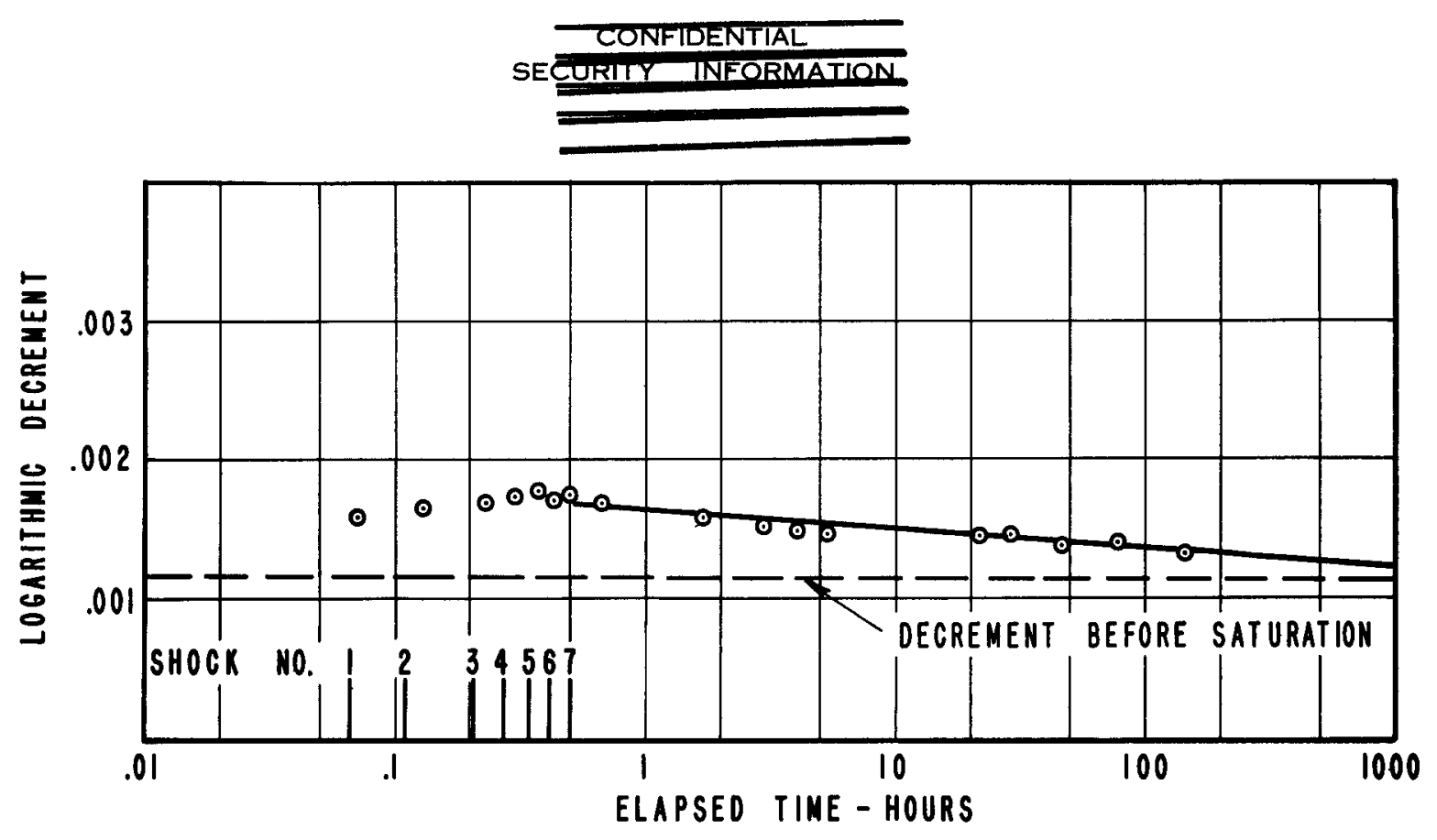

FIGURE 5 RECOVERY OF DECREMENT AFTER A SATURATED MECHAN I CAL SHOCK. BAR NO. $6339-B-22$.

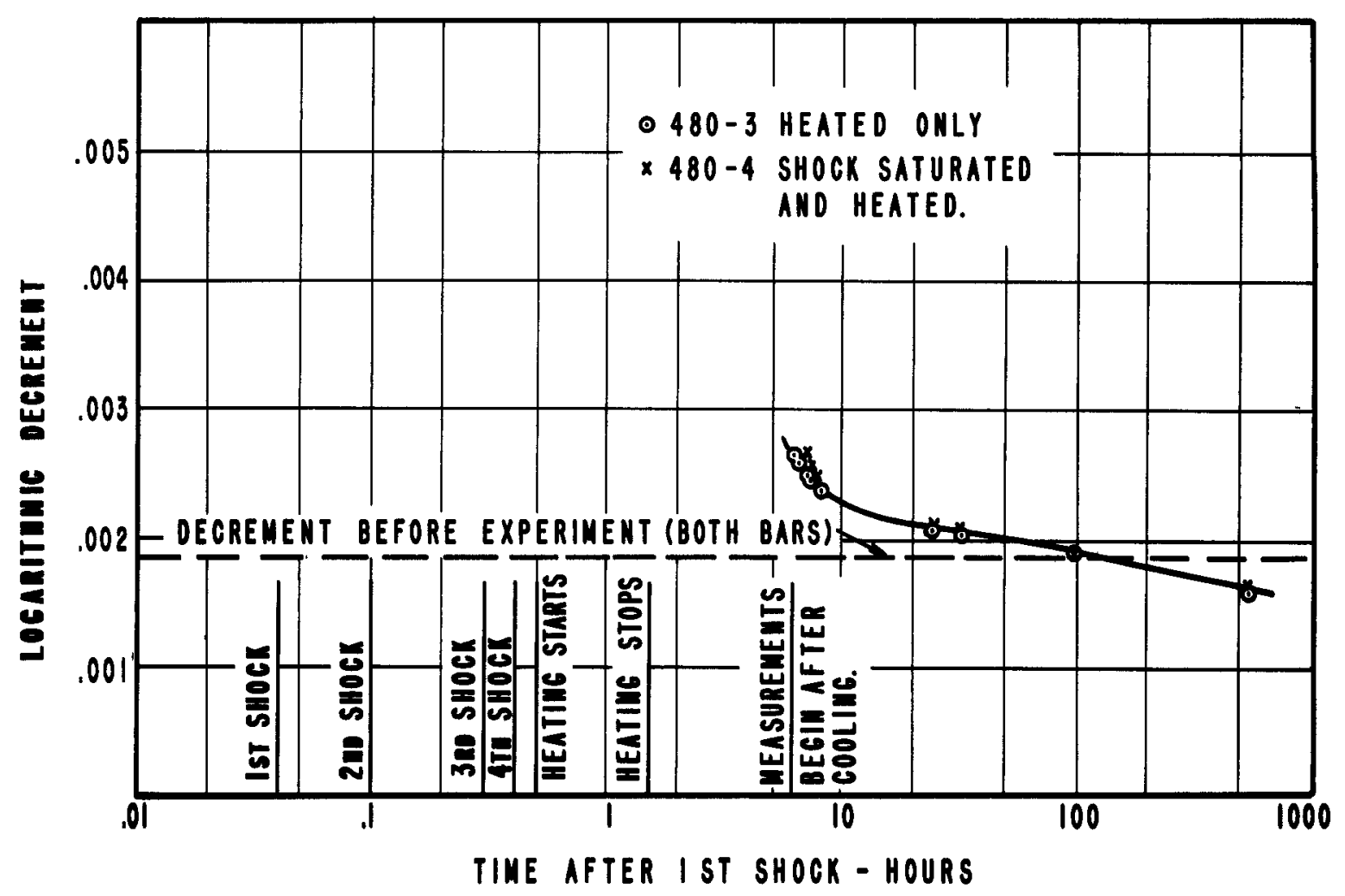

FI OURE - COMPARISOM OF THE RECOYERY OF DECREMENT OF TWO BARS. WHE CHFHAVE BEEN HEATED TO $30 O$ OC FOR I HOUR.

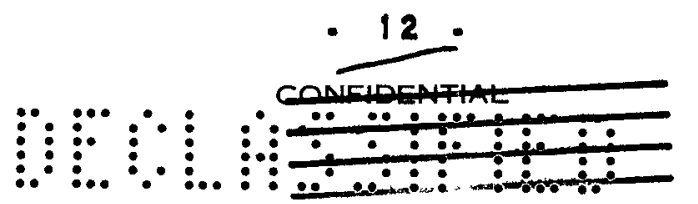

